\title{
FACTORS INFLUENCING COMPETITIVENESS OF SMALL AND MEDIUM INDUSTRY OF BALI: PORTER'S FIVE FORCES ANALYSIS
}

\author{
Jaya Putu Eka Juliana*, Yuliarmi Ni Nyoman \\ Faculty of Economics, Doctoral Program in Economics, University of Udayana, Bali, \\ Indonesia \\ *E-mail: wawaarjaya@yahoo.com
}

\begin{abstract}
Small and Medium Industry (SMI) is a stimulus for the Indonesia. The existence of SMI is not only contributes significantly to GDP but also to absorb labour, and to even the distribution as a result of development and poverty reduction. The SMI has also given its role as a safeguard for the national economy during the crisis. SMI has made a significant contribution to the development of the Indonesian economy, especially Bali, through export, trade and any supporting sectors for employment growth. Along with the globalization, SMI must increase competitiveness in order to survive. This literature review seeks to explore and find various influential factors and competitive strategies to improve SMI competitiveness in Bali with an analysis of Porters' Five Forces. The method used is descriptive based on scientific journals.
\end{abstract}

\section{KEY WORDS}

Competitive strategy, SMI, Porter five force, competitiveness, Bali.

Long-term economic development shown by GDP growth will bring a fundamental change in the economic structure, from the traditional economy to agriculture as the main sector towards a modern economy dominated by non-primary sectors, especially manufacturing industries with increasing returns to scale (positive relations between dynamic output growth and productivity growth as the main motor driving economic growth (Weiss, 1988). This is shown by the rapid growth from year to year in Indonesia's non-primary sector namely Small and Medium Industries (SMI). In Indonesia, SMI has a strategic role in the national economy. This can be seen from the number of business units reaching 3.4 million units in 2013 , or more than $90 \%$ of the national industrial business units. This role is also reflected in the absorption of SMI workers that absorbed more than 9.7 million people in 2013, or $65.4 \%$ of the total employment of the non-oil and gas industry sector (Ministry of Industry, 2015). In accordance with national data, SMI in Bali also shows a significant contribution to the economy of Bali Province. Based on data from the Department of Industry and Trade of the Province of Bali in Table 1, it can be seen that the raw materials / supporting material SMI values in Bali Province amount to Rp. 4,098,246,861. The role of the SMI in the development of a country's economy is evidenced by the reduction in unemployment and the creation of new businesses that continue to emerge (Delmayuni et al., 2017).

Table 1 - Recapitulation of the Directorate of Creative Industries in Bali Province in 2017

\begin{tabular}{cccccc}
\hline Regency / City & $\begin{array}{c}\text { Number of } \\
\text { Business Units }\end{array}$ & $\begin{array}{c}\text { Labor } \\
\text { (People) }\end{array}$ & $\begin{array}{c}\text { Value of } \\
\text { Investment }\end{array}$ & Production Value & $\begin{array}{c}\text { Value of raw materials / } \\
\text { supporting material }\end{array}$ \\
\hline Jembrana & 1.75 & 8.712 & 73.933 .433 & 429.536 .074 & 284.958 .545 \\
Tabanan & 878 & 7.606 & 542.345 .198 & 567.236 .330 & 358.676 .878 \\
Denpasar City & 4.074 & 30.862 & 282.899 .240 & 1.416 .526 .146 & 381.970 .595 \\
Badung & 1.23 & 14.943 & 72.444 .562 & 1.246 .268 .358 & 1.060 .316 .303 \\
Gianyar & 943 & 15.058 & 2.989 .867 .354 & 4.841 .849 .850 & 1.662 .678 .726 \\
Bangli & 4.167 & 11.741 & 24.371 .701 & 363.330 .010 & 150.530 .143 \\
Karangasem & 512 & 4.21 & 25.737 .579 & 32.213 .224 & 20.447 .486 \\
Klungkung & 461 & 4.617 & 29.274 .729 & 92.890 .481 & 54.968 .495 \\
Buleleng & 977 & 6.22 & 22.012 .121 & 183.092 .572 & 123.699 .691 \\
\hline Total & 14.992 & 103.969 & 4.062 .885 .917 & 9.172 .943 .045 & 4.098 .246 .862 \\
\hline
\end{tabular}

Source: Department of Industry and Trade of Bali Province. 
The enactment of the ASEAN Economic Community (MEA) along with free trade agreements (Free Trade Agreement) between countries in ASEAN, has opened opportunities for SMI players to enter new markets. Indonesian SMI must improve product quality to be able to compete in the ASEAN market and more broadly on the world market. SMI also faces many problems, namely limited working capital, low human resources, and lack of mastery of science and technology (Sudaryanto and Hanim, 2002). Another obstacle faced by SMI is the connection with unclear business prospects and unstable planning, vision and mission. The opportunities and challenges that exist, make the SMI must have careful preparation especially for the SMI drivers in Bali. To that end, SMI Bali requires a strategy that will make these SMI competitive.

According to a scientific article by Chirantan Basu entitled "The Importance of Porter's Diamond \& Porter's Five Forces in Business", in an effort to achieve economic profit, various competitiveness analysis models have been developed such as the model of five forces Porter analysis, diamond Porter model, Nine-Power Factor model International Competitiveness and others. Each analysis has its own character so that its use is adjusted to the needs and conditions. For example, the five-forces porter model covers more than five factors (bargaining power of suppliers, bargaining power of buyers, threat of new entrants, threat of substitute product or service, rivalry among existing firms) that directly affect the competitive level of an effort in industrial world by emphasizing industrial structure and profit margins. On the other hand, the Diamond Porter model discusses the four factors (factor conditions, demand conditions, company strategies, supporting industries) that affect the competitive environment of a country and industry in that country. Diamond porters also add another factor: the role of government and chance, which is said to have an important role in creating National Competitive Advantage (NCA). The main point of the Diamond Model, Porter suggests a model of self-reinforcing competitiveness, in which domestic competition stimulates the growth of industry and simultaneously forms sophisticated consumers who always want improvement and innovation. Furthermore, DM also promotes industrial clusters. Broadly speaking, the main difference between the two models lies in its function, where the five forces porter model is useful in helping a company to evaluate the industry being operated with the aim of determining the industrial structure and profit margins, while the Diamond Porter model functions in assisting competitive profit analysis owned by a company against a competing company or rival.

Putra and Maulana (2018) show that company performance can be determined by internal and external factors. Both of these factors must be considered in the SWOT analysis. The research also considers it necessary to optimize the supporting components of the Diamond Porter Creative Industry so that the competitiveness of the Indonesian Creative Industry is increasing amidst the world industrial market. The Diamond Porter model can be seen in Figure 1.

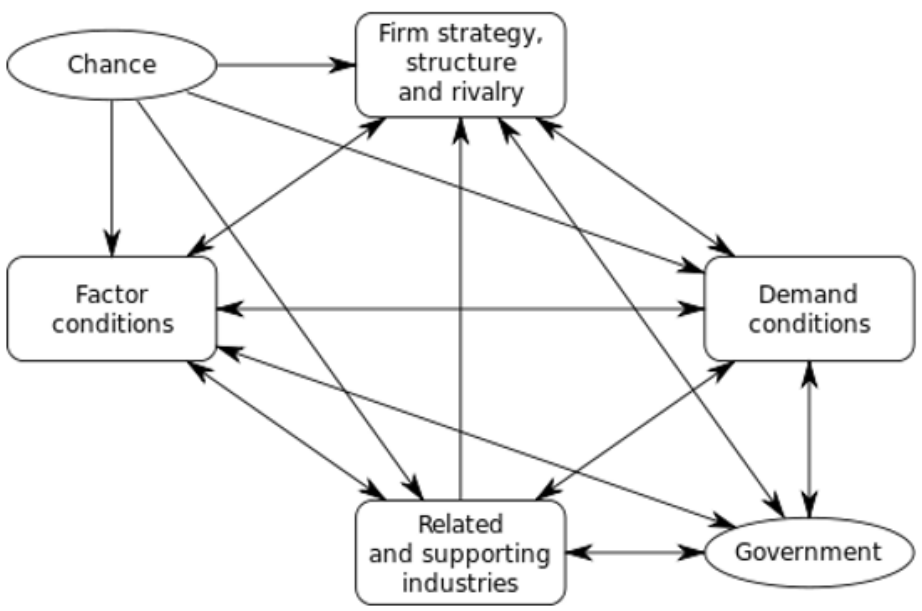

Figure 1 - Porter's Diamond Model (Source: Porter, 1990) 
In addition to the Porter Diamond Model above, there is also a competition theory proposed by Michael Porter that can be used to analyze competition, how a competitive environment will affect the marketing of a product, namely the theory of "Porter 's Five Forces Model". Porter believes that companies are not only competing with companies in the industry today. The model in Figure 2 can describe the business situation that is being carried out and can also help in knowing the advantages of the current and future competition positions. So that companies can increase strength, anticipate weaknesses and avoid companies in making wrong decisions.

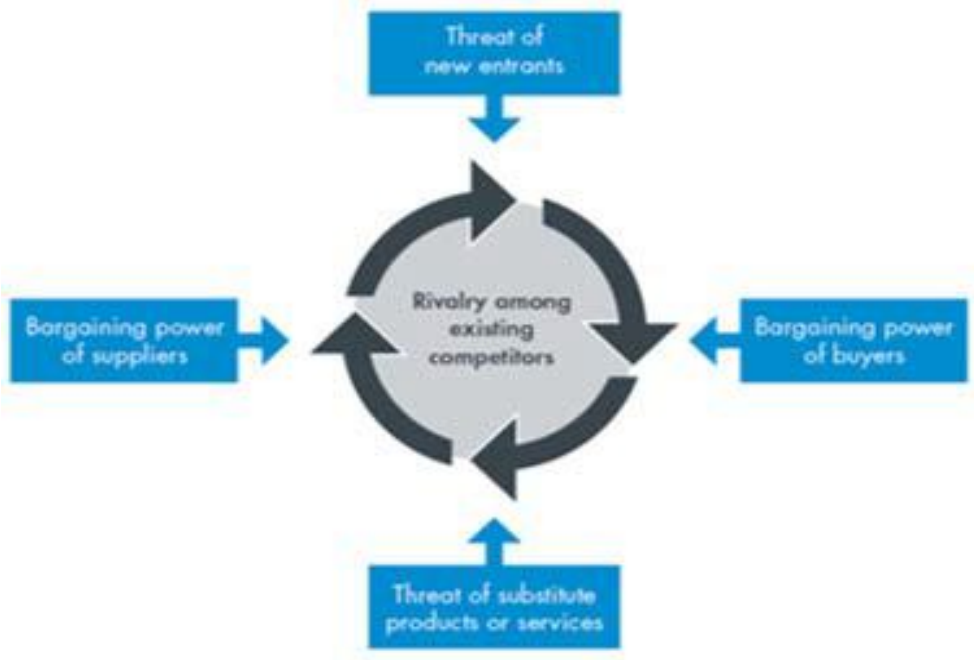

Figure 2 - Porter's Five Forces Model (Source: Porter, 2000)

Meanwhile, Dong-Sung Cho (2003) made modifications to the Diamond Porter Model because there were several disadvantages to the model. The modification model is known as the nine-factor model. The nine-factor model has four physical determinants of international competitiveness, namely the resources bestowed, the business environment, related industries and supporters, and domestic demand. In addition to physical factors, there are also four human factors, namely workers, politicians and bureaucrats, entrepreneurs and professional managers and engineers. While external opportunity events are the ninth factor, as in figure 3.

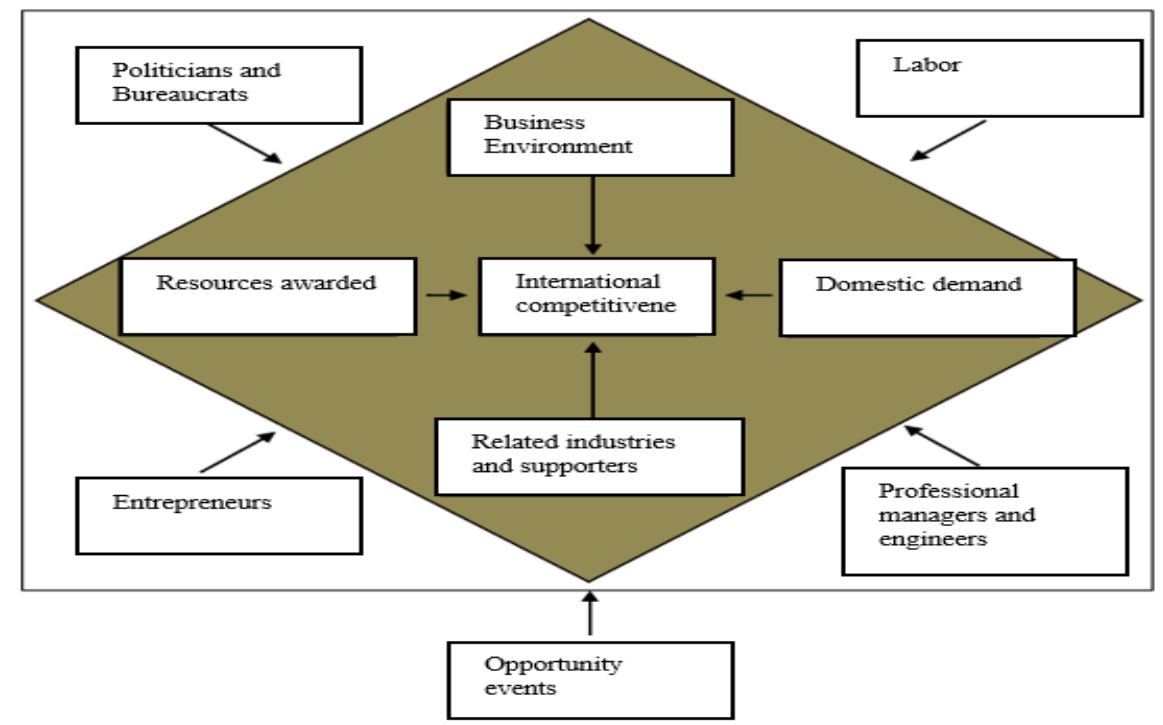

Figure 3 - Model Nine Factors of International Competitiveness (Source: Cho, 2003) 


\section{RESULTS AND DISCUSSION}

Companies formulate strategies to pursue competitive advantage when they strive to improve or maintain their performance through independent actions in certain markets or industries. By using effective competitive strategies, organizations find industry opportunities and learn about customers (Pearie John, 2008). Competitive advantage is the heart of the company's performance in competitive markets. Basically, competitive advantage grows from the value that the company can create to its buyers. The value offered is certainly something different and not owned by competitors. This value or benefit is paid by the buyer for the product or service produced by a company. To create and shape the value needed a variety of careful planning and appropriate strategies, one of which is good management. (Rahma and Pradhanawati, 2015).

Competitiveness is productivity which is defined as output produced by labour (Porter, 1990). Competitiveness is a concept that refers to the ability of a company to compete with other companies to create value. Competitiveness can be created or enhanced by applying the right competitive strategy, one of which is to manage resources effectively and efficiently. In addition, the determination of the right strategy must be adjusted to all activities of the company's functions, so that it will create company performance in accordance with what is expected even more and can produce value.

Porter's Five Forces model created by Michael Porter, an expert and professor at Harvard University in 1979 aimed at describing the framework as an analysis of the development of a business. This model can be used for large and small businesses and businesses that are already running or are just starting. Michael Porter has developed the most influential industrial analysis model in the field of industrial competition analysis, while also contributing to the general theory of competitiveness and competitive advantage. The model, consists of five main factors: (1) The bargaining power of suppliers (Bargaining power of suppliers); (2) Bargaining power of buyers; (3) Newcomer threats (Threat of new entrants); (4) Threat of substitute products (Threat of substitute product or service); and (5) Competition between companies in industry (Rivalry among existing firms). This Porter model plays a role in measuring competition intensity, profit potential or industry profitability and for assessing the attractiveness or absence of an industry (degree of attractiveness) (Porter, 2000).

Previous studies by Barney (2007) revealed that competitive advantage is a condition in which a company is able to create economic value more than its competitors. In simple terms, economic value is the difference between the acquisition of benefits felt by consumers who buy products or services purchased.

Factors Affecting Competitiveness of SMI in Bali. Widyasari's (2014) says that there are several internal factors which are problems to compete with, including the problem of scarcity of raw materials; the increase in fuel prices, increases in electricity rates, and increases in labour costs have resulted in high production costs; limited human resources in the field of product design and technology; lack of product promotion; lack of entrepreneurial motivation; most of the machines/equipment used are over 20 years old so they are not efficient; and still low product quality. While a number of external factors are the economic crisis that occurred in export countries such as the US, Europe and Japan, and the weakening of the value of the Rupiah against the US Dollar that has occurred in recent years has resulted in increasingly expensive imported raw material costs. Further said by Widyasari (2014) that the government has taken several steps to overcome these problems, including facilitating international exhibitions in the country; HR training in production technology, financial management and marketing; import of leather raw materials including Australia, Bangladesh and India to meet the demand for raw materials; machine footwear industry restructuring program and leather tanning; and serious efforts from producers and the government to look for new markets outside the export destination countries that are being hit by the crisis.

Competitive Strategies for SMI in Bali. According to Porter (2000) in analyzing competitive strategies can see from several things, namely (1) Porter Generic Strategy which 
is a general competitive strategy of a company, (2) Low Cost Strategy (Cost Leadership) which emphasizes efforts to produce standard products (same in all aspect) with a very low cost per unit, (3) Product Differentiation Strategy (Differentiation) by encouraging companies to be able to find their own uniqueness in the target market, and (4) Focus Strategy used to build competitive advantage in a market segment that tighter. Analysis of business development strategies based on the five forces Porter approach is carried out by evaluating 5 conditions, including competition conditions among rival companies, potential entry of new competitors, potential development of substitute products, bargaining power of suppliers and bargaining power of consumers.

Competition between rival companies is usually the most powerful of the five competitive forces. According to Porter (2000: 12), the strategy carried out by a company can succeed only to the extent that it produces a competitive advantage over the strategies run by competing companies. Changes in strategy by one company may be responded to with countermeasures, such as price reductions, quality improvements, feature enhancements, service provision, extended warranty, and intensified advertising. Competition between companies occurs because one or more competitors feel pressure or see opportunities to improve positions.

According to Pearce and Robinson (2008) strategy is a large-scale plan, aiming at the future to interact with competitive conditions in order to achieve company goals. Whereas according to Mintzberg (1995), the strategy is a pattern or plan that integrates the main goals of an organization, policy and sequence of activities into a unity. A well-structured strategy can help, organize and allocate organizational resources into an active and distinctive activity based on internal competencies and relative weaknesses of the company and can anticipate environmental changes.

Another opinion by Barney (2002) defines strategy as a company theory about how to compete successfully. In general, the implementation of company theory on how to compete will have three implications for the company's competitive position, namely: (1) competing very successfully to obtain competitive advantage, that is if the actions of companies in an industry or market are able to provide added value and if there are only a few (few) companies capable of carrying out similar actions; (2) compete successfully to gain competitive parity, that is if the actions of companies in an industry or market are able to provide added value and enough companies are able to take similar actions; (3) compete unsuccessfully to obtain competitive disadvantage, that is if the actions of companies in an industry or market fail to provide economic added value.

According to Tambunan (2001), the level of competitiveness of a country in the international trade arena is basically determined by two factors, namely the comparative advantage factor and the competitive advantage factor. Furthermore, the factor of comparative advantage can be considered as a natural factor and a competitive advantage factor is considered a factor that is acquired or can be developed/created. In addition to these two factors, the level of competitiveness of a country is also influenced by what is called Sustainable Competitive Advantage (SCA). This is especially in the framework of facing the level of global competition that is increasingly becoming so tight or Hyper Competitive.

Previous research by Rahma and Pradhanawati (2015) produced findings that are based on the five forces porter method, so that the business strategy that can be developed by SMI Lunpia Kings is a low-cost strategy, where Lunpia Kings SMI are expected to increase the focus of efforts to create Lunpia products at relatively low prices to reach the middle-class segment.

The results of Ikhsani and Budiningharto's (2015) mention that the analysis of industrial competitiveness can be done using industry analysis of five strength models of the Porter model. The five Porter powers will influence how much the competitiveness of an industry in a market. According to Porter, the industry competition is influenced by several factors, including the intensity of competitive competition between competitors (existing competitive rivalry between competitors), the strength of the providers (bargaining power of suppliers), the strength of consumers (bargaining power of customers), the threat of newcomers (threat 
of new entrants), Threats from threat of substitute products. Based on the analysis of Michael Porter's strength, it can be seen that the results of the bargaining power of suppliers, bargaining power of buyers, the threat of new entrant, and the Threat of substitute products show that these factors illustrate favourable competition for the metal processing industry in Ceper. Whereas for the existing competitive factor, the rivalry between competitors describes the negative competition and tends to be unprofitable for the metal processing industry in Ceper.

Based on previous research by Nurhayati (2016) who examined the competitiveness of SMI Batik in Indonesia, it was found that increasing the competitiveness of batik SMI in Indonesia could be done by examining the dimensions of competitiveness in order to have an advantage to compete in the Asian free trade arena (AEC) There are several strategies that must be put forward in an effort to increase competitiveness, one of which is through improving the quality of human resources. The more effective formation of $\mathrm{HR}$ competitiveness of batik SMI actors can refer to the theory by Hitt et al. (2000), that there are several components forming competitiveness in which one with another is continuously interrelated. These components begin with resources that have capabilities, then with their capabilities can be formed core competencies in the company. This core competency must then be developed as a source of excellence to create competitiveness, where companies that have competitiveness can be said as companies that have performance excellence. The linkages between the components forming competitiveness proposed by Hitt et al. (2000) can be explained in Figure 4 below.

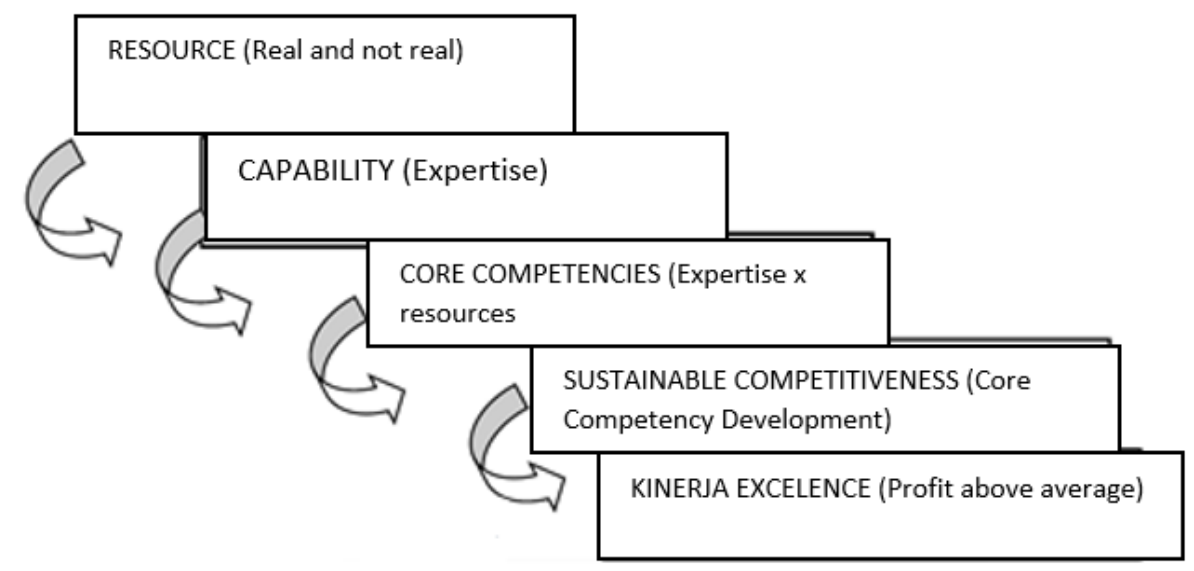

Figure 4 - Components for Forming Competitiveness (Source: Hitt et al., 2000)

Other strategies in an effort to increase competitiveness are through business or business efficiency. Business efficiency implies that in producing goods or services the company achieves economies of scale, namely the scale of a business carried out with a minimum average cost. Economical business scale can be achieved if the turnover or volume is large (large scale). The strategy that can be done by batik SMI is to integrate (collaborate) between one SMI and another SMI. The cooperation that can be carried out includes joint ventures to purchase batik raw materials and colouring drugs. With a joint venture like this, the amount of material purchased becomes large, so that it will obtain efficiency both from the cost of the purchase and from the discounted price. The results of the study show that there are already several batik SMI that have collaborated in purchasing raw materials and colouring drugs (especially imported ones), but not all batik SMI have carried out such cooperation. Therefore the government (local government) must facilitate cooperation in the procurement of raw materials and batik colouring drugs so that they can carry out business more efficiently.

The last strategy discussed in an effort to improve competitiveness is through supporting regulations. The government is the party most responsible for the preservation of batik as an intangible cultural heritage owned by Indonesia. Based on the results of the 
study, it is known that the government has issued policies aimed at protecting Indonesian batik, but the reality in the field shows that the rules made have not fully supported the SMI SMI. Therefore it is necessary to formulate policies that are more pro-SMI, both at the central and regional levels.

Based on the strategies described by Nurhayati (2016), in general, it can also be applied in an effort to develop the competitiveness of SMI in Bali. Improving the quality of resources, both real and unreal, as well as capabilities in the form of expertise and skills of SMI can contribute significantly to increasing the competitiveness of SMI. Both of these are related to Nurhayati's third strategy (2016), namely the role of government in shaping regulations and programs that favour SMI. In addition, a business efficiency strategy that emphasizes a large scale economy is also an innovative proposal that is interesting and potentially promising to be applied to SMI in Bali. This is because there are not many SMI in Bali that collaborates between SMI that can provide more benefits but also reduce the costs needed because of the system of sharing the burden among SMI in collaboration.

Research on other competitiveness was carried out by Putra and Maulana (2018) with the result that efforts to improve the competitiveness of the footwear industry cluster in Tamansari District can be carried out with the following priority strategies, namely promotion and system of selling products online, implementing operational standards and product quality, foster good relationships with employees, buyers and suppliers, and foster good relationships with suppliers, and attend footwear exhibitions. Some of these strategies have been implemented by SMI in Bali, such as fostering good relationships with economic actors (suppliers, traders, buyers) because SMI in Bali to adopt a traditional family system and are close to each other. Another strategy is the affirmation of a more systematic work environment such as online marketing and sales. This is taking into account the economic situation of the MEA and globalization and the development of science and technology which has led to a shift in trends from offline to online business. In addition, the application of SOPs and quality control and actively participating in exhibitions can be innovative strategies that can be applied in the effort to develop the competitiveness of Bali SMI.

The results of other previous studies conducted by Hubeis and Pandjaitan (2012) show a strategy to increase SMI competitiveness by (1) increasing collaboration to maintain continuity of raw material availability between regions; (2) building SMI product industrial areas; (3) increasing the role of private and tertiary government through development research. With the large number and variety of SMI in Bali, the strategies used are not the same for each SMI.

The results of the Lestari et al. (2013) states that based on the Revealed Comparative Advantage (RCA) analysis method and the Competitive Profile Matrix (CPM) analysis the priority strategies that can be taken to improve the competitiveness of Indonesian processed tuna are to pay attention to production and marketing factors, such as (1) improving processed Indonesian tuna, (2) encouraging overcoming tariff and non-tariff barriers, (3) increasing market development and promotion knowledge. Strategic priorities for human factors and institutions are (1) increasing the government's role in developing the tuna processing industry, (2) increasing human resource capacity that is able to handle quality, (3) eradicating and controlling illegal fishing. Based on CPM analysis, the three factors of production and marketing greatly influence the competitiveness of tuna, namely (1) the quality of processed tuna produced, (2) tariffs and non-tariffs and (3) development and promotion markets.

Research by Sudaryanto et al. (2013) stated that the strategy to develop SMI in Indonesia was inseparable from banking support in lending. Currently, the credit scheme that is very familiar in the community is the People's Business Credit (KUR), which is specifically intended for SMI with a decent business category, without collateral. In addition, the strengthening of SMI companion institutions can be done through easy access and increased capacity building in the form of training and research activities that support the provision of credit to SMI. While the strategy to anticipate an increasingly open and competitive market mechanism, especially in the ASEAN region, is market control, which is a prerequisite for increasing the competitiveness of SMI. The way that can be done in order to master the 
market is through the ease and speed of SMI to obtain information, both information about the production market and the production factor market to expand the product marketing network produced by SMI. Information technology applications in SMI will facilitate SMI in expanding markets both domestically and overseas markets efficiently. The establishment of an IT-based SMI Development Center is considered capable of encouraging the growth and development of micro, small and medium enterprises in the current era of information technology.

On the other hand, there have been debates that have arisen over the past few decades among scholars who consider Porter's principle of five forces to be irrelevant to the development of present economic conditions (O'shaughnessy, 1984; Speed, 1989; Dulčić et al., 2012). The most common argument from the counter side is that the rapid and rapid progress of science and technology has changed the conditions of the industrial and market environment. The study by Karagiannopoulos et al. (2005) emphasizes mainly about the magnitude of the impact of internet utilization on current economic developments. Pre the soaring popularity of the internet, in general, every industry has a separate physical body and information body, where these conditions result in difficulties in accessing information to the industry concerned and influencing the competitive potential of the developing industry. Another argument states that Porter's model of five forces is too static and inflexible to changing trends such as ethnic composition in an increasingly varied population and new technological innovations and does not consider time or time, so it is difficult to apply the principle of five forces to the environmental markets that have dynamic competitive properties (Dess et al., 2005). The five forces Poter model also tends to ignore the role of individual companies and only focus on industry and group structure (Indiatsy et al., 2014).

Nevertheless, the study by Dalken (2014) states that Porter's model of five forces is still relevant, even in the conditions of modern economic development today. Constantinides and Zalewska-Kurek argue that there are three new forces, namely Globalization, Digitalization and Deregulation. However, the three new forces only affect and do not restructure so that the five forces Porter model is considered still applicable to use. The basic principle by which a business runs based on elements of Buyers, Suppliers, Substitutes, New Entrants and Competitors is still valid and valid even in the current economic development. For example, Bargaining Power of Buyers is increasing because of very easy access to information through the presence of the internet. On the other hand, the Threat of New Entrants has been reduced due to the large investment demands, especially in the technological aspects, thus suppressing the potential for new competitors to emerge in the market.

\section{CONCLUSION AND SUGGESTIONS}

The magnitude of the potential of SMI in Bali needs to get attention for the progress of the Indonesian economy, so as to be able to prosper the community; one of them is due to reduced unemployment and the creation of new businesses. By utilizing five Porter models of strength or as a basis, SMI in Bali can understand the actions needed, such as implementation, other processes, and techniques that can contribute to creating a competitive advantage for the organization. By using this process, an organization has a guide to take the steps needed to achieve a fairly comprehensive strategy to create a competitive advantage. For this reason, Bali SMI need a competitive strategy that will make these SMI competitive, namely Porter's generic strategy, Cost Leadership, Product Differentiation strategy, and Focus strategy.

\section{REFERENCES}

1. Anggraeni, S. K. 2017. Strategi Peningkatan Daya Saing Usaha Kecil Menengah Berbasis Olahan Ikan di Indonesia: Suatu Tinjauan. Journal Industrial Services Vol. 3c No. 1. 
2. Angkasa, W.I. Hubeis, M, and Pandjaitan, N.K. 2012. Strategi and Kelayakan Pengembangan Lembaga Intermediasi untuk Meningkatkan Daya Saing Usaha Kecil and Menengah di Indonesia. Jurnal Manajemen SMI, September 2012 (95-101) Vol. 7 No. 2.

3. Barney, B.J. 2007. Gaining and Sustaining Competitive Advantage third edition. New Jersey: Pearson Prentice Hall.

4. Barney, J. B. 2002. Gaining and Sustaining Competitive Advantage. Addison Westley Reading: Mass.

5. Basu, Chirantan. "The Importance of Porter's Diamond \& Porter's Five Forces in Business." Small Business - Chron.com, http://smallbusiness.chron.com/importanceporters-diamond-porters-five-forces-business-33891.html. Accessed 29 April 2019.

6. Dälken, F. 2014. Are Porter's Five Competitive Forces still Applicable? A Critical Examination concerning the Relevance for Today's Business. Thesis of Faculty of Management and Governance, University of Twente.

7. Dangayach, G.S., Deshmukh, S.G. 2001. Manufacturing strategy, literature review and some issues. International Journal of Operations and Production Management, 21(7), 884-932.

8. Delmayuni, A., Hubeis, M., \& Cahyadi, E. R. 2017. Strategies to Increase the Competitiveness of Food's Small Medium Enterprises (SMI) in Palembang. Buletin IImiah Litbang Perdagangan.

9. Dess, G. G., Lumpkin, G. T. and Eisher, A. B. 2006. Strategic Management Text and cases International edition. London: McGraw-Hill.

10. Dulčić, Ž., Gnjidić, V., \& Alfirević, N. 2012. From five competitive forces to five collaborative forces: revised view on industry structure-firm interrelationship. ProcediaSocial and Behavioral Sciences, 58, 1077-1084.

11. Ikhsani, M. M., \& Budiningharto, S. 2011. Analisis Daya Saing Industri Pengolahan Logam di Kecamatan Ceper, Kabupaten Klaten Jawa Tengah. E-Journal Fakultas Ekonomi, Universitas Diponegoro, Semarang.

12. Indiatsy, C. M., Mwangi, M. S., Mandere, E. N., Bichanga, J. M., and George, G. E. 2014. The Application of Porter's Five Forces Model on Organization Performance: A Case of Cooperative Bank of Kenya Ltd. European Journal of Business and Management.

13. Irmawati, Setyani. 2015. Strategi Peningkatan Daya Saing Industri Unggulan Provinsi Jawa Tengah Untuk Menghadapi Asean Economic Community (AEC) 2015. Jurnal Ekonomi Pembangunan FE Universitas Negeri Semarang.

14. John, Pearie and Robinson. 2008. Manajemen Strategis, Edisi ke-10. Jakarta: Salemba Empat.

15. Karagiannopoulos, G. D., Georgopoulos, N., and Nikolopoulos, K. 2005. 'Fathoming Porter's five forces model in the internet era'. Info Journal. Vol.7 No.6 (2005), pp.66-76. Emerald Group Publishing Limited

16. Lestari, W., Syarief, R., \& Sumantadinata, K. 2013. Strategi Peningkatan Daya Saing Tuna Olahan Indonesia di Pasar Internasional. Manajemen SMI Vol. 8 No. 1.

17. Muhardi. 2007. Strategi Operasi.Yogyakarta: Graha Ilmu.

18. Nurhayati, S. 2016. Strategi Penguatan Daya Saing Usaha Kecil and Menengah (SMI) Batik Menghadapi Asean Economic Community (AEC). Jurnal Ekonomi and Bisnis. Vol. 19, No. 2.

19. O'Shaughnessy, J. 1984. Competitive marketing : a strategic approach. Boston (Mass.): Allen and Unwin.

20. Pearce and Robinson. 2008. Manajemen Strategis. Jakarta: Penerbit Salemba Empat.

21. Porter, Michael E. Porter. 1990. The Competitive Advantage of Nations. Free Press

22. Porter, Michael E. Porter. 2000. The Competitive Advantage of Nations. Free Press

23. Putra, G. S., \& Maulana, N. 2018. Strategi Meningkatkan Daya Saing Industri Kreatif Indonesia: Studi Kasus Pengembangan Klaster Industri Alas Kaki Kecamatan. Ultima Management, Vol. 10, No. 2.

24. Rahma, A. N., \& Pradhanawati, A. 2018. Strategi Bersaing Produk SMI Lunpia Dengan Menggunakan Analisis Five Forces Porter and Swot (Kasus Pada SMI Lunpia Kings Semarang). Jurnal Ilmu Administrasi Bisnis, Vol. 7 No. 2. 
25. Russell, S., H. Millar. 2014. Competitive Priorities of Manufacturing Firms in the Caribbean. Journal of Business and Management (IOSR-JBM).

26. Speed, Richard J. 1989. Oh Mr Porter! A Re-Appraisal of Competitive Strategy. Marketing Intelligence and Planning 7 (5/6), 8-11.

27. Sudaryanto and Hanim, Anifatul. 2002. Evaluasi kesiapan SMI Menyongsong Pasar Bebas Asean (AFTA): Analisis Perspektif and Tinjauan Teoritis. Jurnal Ekonomi Akuntansi and Manajemen, Vol 1 No 2.

28. Sudaryanto, Ragimun. 2013. Strategi Pemberdayaan UMKM Menghadapi Pasar Bebas Asean. Yogyakarta: Kedaulatan Rakyat.

29. Tambunan, T. 2001. Perdagangan Internasional and Neraca Pembayaran, Teori and Temuan Empiris. Jakarta: LP3ES.

30. Widyasari, Deasy. 2014. "Analisis Industri Alas Kaki di Dki Jakarta Tahun 2014 Dengan Model 'Porter's Five Forces”. Jurnal Fakultas Ekonomi, Universitas Budi Luhur, Jakarta. 